\title{
Frequência e os aspectos epidemiológicos de afecções podais em ovinos na região da Zona da Mata do estado de Alagoas
}

Emikael da Silva Lima*, Kaique Myke Nascimento Brito, Erik Rocha Lira Martins, Walter Franklin Bernardino Leão Filho, Jéssica Taiane Gomes Gregório, Franklin Oliveira da Silva, Anne Catherine Laurindo Santos, Elyse Viana de Melo, Gildeni Maria Nascimento de Aguiar

Curso de Medicina Veterinária, Unidade Educacional de Viçosa, Universidade Federal de Alagoas (UFAL), Arapiraca, AL, Brasil

*Autor correspondente

e-mail: emikael.vet@gmail.com

\section{Resumo}

As enfermidades podais geram grandes perdas à ovinocultura, no entanto, muitas vezes elas não são corretamente identificadas. Em virtude da escassez de artigos relacionados a essa temática no Estado de Alagoas, o objetivo deste trabalho foi estabelecer a frequência das doenças podais e os fatores que predispõem a sua ocorrência nas propriedades de ovinos na região da Zona da Mata alagoana. Foram realizadas visitas às propriedades e aplicados questionários epidemiológicos semiestruturados para obtenção das informações referentes ao sistema de manejo e ocorrência anterior da doença. Na oportunidade da visita, todos os animais foram examinados, identificados os enfermos e registradas as lesões. Entre junho/2016 a fevereiro/2017, foram visitadas oito propriedades nos municípios de Viçosa, Chã Preta, Paulo Jacinto e Tanque D'arca. Foram examinados 290 animais, entre mestiços das raças Dorper e Santa Inês. 0 tamanho dos rebanhos variou entre 14 e 72 animais. De acordo com os proprietários, em algum momento os ovinos manifestaram um quadro de claudicação. No entanto, apenas uma $(12,5 \%)$ das propriedades não apresentou animais acometidos no momento da visita. 15\% (40/290) dos animais apresentaram pelo menos um tipo de alteração, em um ou mais cascos, totalizando 66 membros acometidos. A avaliação clínica identificou que a dermatite interdigital foi mais frequente, acometendo 47,5\% (19/40) dos animais e afetando 32 membros, seguida da pododermatite interdigital em 32,5\% (13/40), com 14 membros doentes. Em seguida, crescimento excessivo dos cascos em 30\% (12/40), lesionando 18 membros, e abscesso do casco em 5\% (2/40) dos animais, comprometendo 2 membros. Dos animais com pododermatite infecciosa, 62,2\% (9/13) apresentavam escore 2, 5,4\% (2/13) apresentavam escore 3 e 15,4\% (2/13) escore 4. Os animais jovens (até 1 ano e meio) foram os mais acometidos (22), sendo observados mais casos de dermatite interdigital. 13,6\% (28/205) ovinos mestiços da raça Dorper e 14,11\% (12/85) mestiços Santa Inês apresentaram alguma alteração nos cascos. 0 tipo de solo não influenciou na frequência das lesões, no entanto, nas propriedades 
com maior número de doentes, existiam áreas úmidas, pastejo em margens de açudes ou em regiões de vazantes. Em quatro propriedades utilizou-se antibióticos parenterais como forma de tratamento; em apenas uma delas houve resultado satisfatório. Embora a utilização dos antibióticos seja recomendada, o uso dessa alternativa deve estar associado a outras medidas, como manutenção dos animais acometidos em ambientes secos durante o tratamento; a não adoção dessa medida, o uso de doses incorretas e período curto de tratamento comprometem o êxito no tratamento instituído. Uma das propriedades realizou o pedilúvio e outra, o casqueamento corretivo, afirmando ter sucesso nessas práticas. Atenção deve ser destinada às doenças podais nos ovinos, visto que a região estudada apresenta condições ambientais favoráveis à manifestação da doença, o que pode levar a prejuízos significativos a ovinocultura do estado. 